\title{
実践共同体, 学習者共同体，として知識構築共同体：その違いはどこに？
}

\author{
Marlene Scardamalia \\ (Ontario Institute for Studies in Education of the University of Toronto) \\ 司会・要約 大島 純 (静岡大学)
}

\section{I．学習者共同体としての教室一「ガイドされる発見」 という認識論—}

学習環境のデザインにおける共同体の視点を強調した 代表的な実践研究の一つとして, Brown \& Campione （1990）を中心に展開してきた「学習者共同体」プロジェ クトを挙げることができる。ここでは，学習者共同体を 教室に扔ける社会文化的実践の共同体として実現するた めの授業設計の原則ともいうべき基本構造について概観 し，それを支える根本的な認識論的前提としての「ガイ ドされる発見 (guided discovery)」を検討する。

\section{1. 学習者共同体の基本構造と授業設計}

自らの学習を制御するメ夕認知と，そうした能力を共 同学習という社会的文脈を適切に設計することによって 促進するというトレーニング研究をもとに，教室環境に おいて認知的徒弟制度の実現を目指したのが「学習者共 同体」プロジェクトである。Brown \& Campione (1996) は，学習者共同体を実現するために準拠すべき基本構造 (Figure 1) を示している。Figure 1 に示された 5 つの要 素は, 学習者が自らの学習を展開する上で必要とする資 源や課題構造, そしてそれらを用いてどのような活動を 展開すべきかを要約したものである。

授業を設計する上で，学習者に獲得が期待される理解 (理解すべき専門的知識) は, それがどのように将来利用され るべきものかという課題構造 (必然性のある課題) を提供す ることで導き出す。これらは授業設計時の教材研究とし て丹念に行われるものであり, 通常その領域知識の専門 家 (例光ば生物学者) が関与する。学習を展開する問題空間

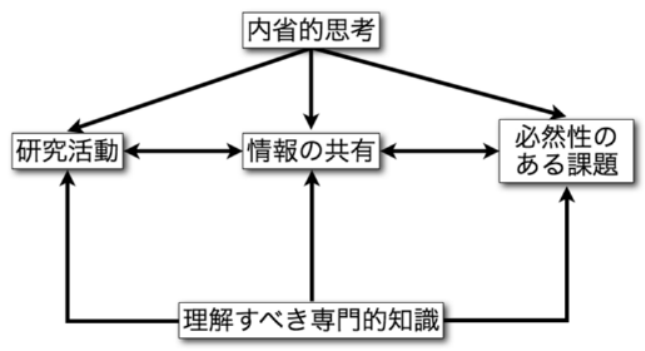

Figure 1 学習者共同体の基本構造
を適切に構築することで, 深い内容理解へ到達させる準 備をすることができる。必然性のある課題は「大きな考 え (a big idea)」として学習者に提示される。学習者はそ の問題を解決すべく，いくつかの細分化された下位課題 を小集団学習で解決していく。課題解決のために必要な 情報は, 単に教師から教えられるわけではなく, 必要な 文献を調查したり，あるいはフィールドに出て情報を収 集したりと，専門家がその問題に取り組む際と類似した 研究活動に学習者は従事する。個々の下位課題の解決案 やそこから導き出された新しい考えは, 最終的課題を解 決するに有用なものであるかどうか，グループ間で情報 を共有しながら検討し合う。また，こうした一連の活動 の進捗や問題点などを俯瞰的に振り返る機会 (内省的思考) も必要となる。

それまでの研究で開発されてきた相互教授法による文 章読解活動は, ジグソー学習法 (Aronson, Blaney, Stephan, Sikes, \& Snapp, 1978) というグループ学習の設計と融合し て, この学習者共同体の根幹をなしている。また, 内省 的思考を促進するために定期的に行われるクロストーク と呼ばれる教室全体でのディスカッションでは, 教師の ファシリテータとしての能力が要求される。

学習者共同体の基本構造に準拠して Brown の研究グ ループが展開してきた絶滅危惧種に関する生物学的学習 においては，その内容理解に著しい向上が見られただけ ではなく，より科学的な対話に学習者が従事できるよう になることが明らかになっている。

\section{2. 学習者共同体実践における問題点一「ガイドされる}

\section{発見」という認識論の限界一}

Brown らの研究成果は, 教室という学習環境がこれ までの「個人の集まりとしての集団」から，「教え合い， 学び合う」文化的実践を展開する学習者共同体として変 革を遂げたことを示している。そのために学習者共同体 がどのような原則に基づいて実現されなければならない かを明らかにした基本的な枠組みは，授業設計において これまでの知見を総合的に融合する上で有効に機能して いる。しかし，こうした研究の背後にある Brown らの 
学習に対する認識論自体が, 21世紀の教育をさらに発展 させるには限界があると筆者は考える。

彼らが準拠する認識論は「ガイドされる発見 (guided discovery)」である。これは, 社会で確立された知識構造 を, 学習者が構成主義の見解に基づいて学習するために 考え出された折衷案である。構成主義的見解では, 学習 者は自らの知識を自発的に構築していくことが重要であ ると考える。しかし, 学習者の自発性だけに委ねてしま うと, 必ずしも深い概念的理解や適切な学習方略の獲得 へは結び付かない。Brown らは,こうした問題を解決す るために, 適切に構造化されたメ夕認知的学習環境にお いて, 学習者が期待される知識を発見的に学習できるよ うな支援を提供する必要があると考えた。学習者は, あ たかも自らの疑問に基づいて研究活動を行い, その上で 自分たちの理解を共有し, そして議論を通じて高め合っ ているかのように設計しておくのである。Brown \& Campione (1994) は，こうしたメ夕認知的な学習環境を, 学習者共同体の儀礼的な特徵だと述べている：

The "repetitive, indeed, ritualistic nature" of FCL activities is "an essential aspect of the classroom” (Brown \& Campione, 1994, p. 236).

彼らの見解は, 決して学習者の自発性を軽んじている わけではない。さらに深く彼らの実践の設計を吟味する と, そこには人間の発達の社会文化的アプローチ (Vygotsky, 1978) の影響が窥える。すなわち, 前述したような学 習者共同体の儀礼的な特徵は, 学習者共同体に対する一 種の「足場掛け（scaffolding）」であり，そうした儀礼を内 在化することによって，学習者自身が学習者共同体の文 化的実践に対してより中心的に参加できるようになるこ とを目指しているのである。

筆者の考える「ガイドされる発見」の認識論の問題点 は, 実はこうした足場掛けの内容と, それが徐々に取り 外されたときに起こる学習の転移現象にある。第 1 の問 題点は, そこでいかに深い概念的理解を学習者が獲得す るにせよ，そのレベルは現在確立されている知識体系を 越える可能性はないことである。第 2 に，儀礼化した実 践活動は，それ自体を疑問視し改善していく実践を含ん でいないのである。この 2 つの問題点は，21世紀の教育 に必要な知識創造実践には欠かせない側面 (Paavola, Lipponen, \& Hakkarainen, 2004) であり，これらの問題点を 適切に克服する術を議論できていない点が学習者共同体 の実践の限界なのである。

\section{II. 知識構築共同体としての教室一「知識創造」という 認識論一}

学習者共同体としての教室の基本的な認識論である
「ガイドされる発見」の問題点を克服する,知識創造の認 識論に基づいた「知識構築共同体 (knowledge building community)」としての教室を筆者は提案する。学習を知識構 築として捉える視点は，真の意味での構成主義に基づい ており (Scardamalia \& Bereiter, 2003)，それまでの作文技 術の研究の成果と, それと並行して行われてきた熟達化 についての研究が基礎に位置づけられる。

\section{1. 知識構築共同体の社会認知的・技術的決定要因}

Scardamalia（2002）は，漸進的な問題解決を継続的に 繰り返す自発的学習が重視される学習環境を実現するた めに必要な12の原則を設定した。

(1)真のアイディアと真正性の高い問題＼cjkstart知識構築実 践共同体は，参加者にとって真正性の高い問題に，自ら のアイディアを提示することで学習をスタートする。ど のような観点からであれば学習内容に学習者が関心を高 く持ち続け，自分の考えをそこに提案し続けることがで きるのかが考慮された学習環境である必要がある。

(2)向上し続けるアイディア 知識構築実践において, 参加者が提案するアイディアは, 誰もがさらに向上させ 続けることができる知識のオブジェクト(概念的道具) とし て捉えられる。アイディアを提案者と切り離して吟味し, 向上させ続けることでその所有権は共同体そのものにあ ると考光る。

(3)アイディアの多様性参加者の提案するアイディ アの多様性は自然に存在し，かつ新しい知識の構築の際 には不可欠な要素である。こうした多様性を不自然な ルールで集約したり，無視したりすることはその実践の 生産性を大きく低下させる。

(4)俯瞰する行為 知識構築実践では, 参加者の提案 するアイディアの多様性をより包含する形で体系化して いく活動が重視される。新しい知識を構築していくため の適切な問題意識を醸成するために，当初から持ってい た観点による分類とは別に，共同体全体として持ってい る知識やアイディアを新しい観点からまとめ上げること が要求される。

(5)認識論的主体性 知識構築実践では, 何を解決す るための知識を構築していくかだけでなく，どのように 知識を構築していくかも実践共同体の参加者に委礼られ ている。すべての参加者が自らのアイディアと他者のア イディアの関係性について言及し，新たな枠組みを提案 し続ける。こうした知識発展のマネジメントの側面は, マネジャーと思しき特定の個人が担うのではなく(教室環 境では多くの場合关机が教師であるわけだが)，参加者全員の 「集団的認知責任 (Collective Cognitive Responsibility)」であ る。

(6)共同体としての知識，そのための集団的責任 
識構築実践共同体の目標は，共同体レベルの知識発展で ある。そこに参加する個人は，この共同体としての知識 の発展に寄与する責任を持つ。

(7)知識の民主化 すべての参加者は共同体としての 知識発展の貢献者となる。参加者はそこに見られた知識 の発展にプライドを持てなければならない。そこには成 功者と失敗者等の区別はなく, 全員が知識の創造に対し てより強勒となる。

(8)対称性を持つ知識発展知識構築実践共同体の参 加者の間，あるいは異なる実践共同体の間で知識は分か ち持たれている。それ故に, 参加者同士, 共同体同士で 知識の交換が生じる。このとき，知識を与える側と受け 取る側に区別されるわけではなく, どちらもが与えそし て受け取るという構図ができる。

(9)普及する知識構築 知識構築実践に参加すること を通して, 学習者の学習に対する意識が拡張されること が期待される。特定の仕事, 学習単元において知識構築 的であるだけでなく, 常に知識構築的な精神世界を確立 する。

(10)権威のある資源の建設的な利用 知識構築実践で は, 学習者自らが知識を構築していく領域の最先端の知 見に触れる必要がある。そうした現状での優れた知識に 対する尊敬を持ちながらも，そのもの自体を絶対化する ことなく批判的に論じる姿勢を忘れない。

(11)知識構築の対話 知識構築実践共同体で展開する 対話は，知識を共有するだけでなく，終わることのない 知識発展を目標とした実践を通して，それを改善し変換 させ続ける。

(12)埋め込まれ変換される評価評価自体, 知識構築 実践の一部であり, 実践の中に埋め込まれている。知識 構築共同体では, より適切でかつ厳密な評価が自ら行わ れる。

こうした知識構築実践が教室環境の学習活動において 実現するためには, 学習者自らが所属する共同体の知識 発展を自由にマネジするための学習環境ツールが必要と なる。そのために開発されてきたのが, Knowledge Forum $^{\circledR}$ (以前は CSILE) という協調学習支援環境 (ComputerSupported Collaborative Learning : CSCL) システムである (例 えば, Scardamalia, 2002)。Knowledge Forum ${ }^{\circledR}$ は，学習 者自体が自己学習活動を協調的に制御するために必要と なる「足場掛け (scaffolding)」機能が装備されたデータ ベース型の学習環境である。

\section{2. 学習者共同体としての教室との対比一「知識創造」の 認識論一}

知識構築共同体としての教室では, 学習を知識が創造 されるときに典型的に見られる漸進的な問題解決活動と
して捉える認識論が前提となる。ここでは,「ガイドされ る発見」と「知識創造の認識論」から導き出される学習 活動のデザインを対比することでより明確な区別を試み る。

(1) 学習内容 (知識)

学習者共同体の対象知識は, 非常に広範囲にわたって その探究が可能となるような領域固有の知識である(例 えば，絶滅危惧種，飛行機はなぜ飛ぶのか，光，など)。通常これ らのテーマは, その課題構造に応じて下位トピックに分 割され，そのいずれかを学習者グループが担うことにな る。

選択されるテーマは, 知識創造の認識論に基づく知識 構築共同体でも類似したものとなるが，学習はその課題 を下位課題に分割したトピックの学習によって始まるわ けではない。むしろ，そこから派生する様々な問題意識 が学習の起点となる。そこで下位課題が提供されたとし ても，それは従うべき目標ではなく，「そうあるべきか」 を議論する対話のオブジェクトとして取り扱われる。

(2) 学習者の研究活動

学習者共同体では，学習者グループは自分たちの担当 する下位課題のテーマについて十分な理解を獲得するこ とが要求される。Brown らのグループによって採用さ れるジグソー法では，その内容をグループ間で教え合う 活動が付随している。

これに対して知識構築共同体では, 固定的なグループ のメンバーシップを想定しない。個々の学習者は各々が 興味を持ったテーマのグループのメンバーとして参加す るが，それは必ずしも1つとは限らず，流動的となる (Zhang, Scardamalia, Reeve, \& Messina, 2009)。彼らが従事 するのは内容理解ではなく問題を解決することであり, そのための説明を構築することである。こうした問題解 決は漸進的に進展し, 目標は随時変化し続ける。

(3) 協調学習

学習者共同体では, 協調学習は確立した学習参加構造 として設計される。各学習グループ内では, 相互教授法 等を用いて内容理解が協調を通して促進され，さらにそ の理解はジグソー法を用いてお互いに教授される。

これに対して知識構築共同体では，異なるグループの 学習成果は自分たちが知識を進展させるために協同利用 されていく。共同体全体としてどのように知識が進展し 続けているかに関する俯瞰的な視点を持ち，そこに残存 する問題点を洗い出していく。

(4) 教室全体の討論/知識の共有

学習者共同体における教室での討論 (Crosstalk) は, 各 グループの学習成果の報告の場であり, それに対して他 のグループからの質問が提示される。こうした討論の目 
的が主に知識の共有であるのに対して, 知識構築共同体 では, 教室全体としての知識発展を吟味する場として教 室全体の討論が利用される。

（5）到達する活動とその評価

学習者共同体では, 下位課題の学習を通して獲得され たグループの理解を共有し，より大きな問題を解決する ことができることを経験することで学習が終焉を迎える。 これに対して, 知識構築共同体では学習が終わるという 考えは存在せず, 現状の進展の分析と新たな問題の発見 が継続されていく。

こうした比較を通してわかることは, 学習者共同体の 「ガイドされる発見」の認識論では, 新しい知識をつく り上げていく実践に参加するために必要となる能力を学 習者自身が経験し習得する機会が皆無であるのに対して， 知識構築共同体における「知識創造」の認識論では，む しろそうした活動に焦点を置いているという著しい違い である。教室場面での実践をこうした認識論の違いを念 頭に観察しない限り，これまでの実践の最も優れた姿で ある学習者共同体と, それを越えて進展を続ける知識構 築共同体の違いは見えてはこないのである。

\section{III. 知識構築共同体としての教室実現のために必要な こと}

知識構築共同体としての教室に従事する児童・生徒は 必ずしも優秀である必要はない。問題は彼らが学習をど のように捉えるかであり，それを知識構築的なものへと 支援することから始めればよいのである。彼らにとって， 知識は多くの場合個人に内在的なものである。これを彼 らの所属する共同体である教室全体の文化的資産として 共有し，それを向上させていくために必要な行動をとる 姿勢を身につけさせることを目指すべきである。その際， 評価はこうした共同体の持つべき知識の発展がその対象 であり，それを行うのは教師だけでなく児童・生徒すな わち彼ら自身であることを忘れてはいけない。

\section{引用文献}

Aronson, E., Blaney, N., Stephan, C., Sikes, J., \&
Snapp, M. (1978). The jigsaw classroom. Beverly Hills, CA : Sage.

Brown, A. L., \& Campione, J. C. (1990). Communities of learning and thinking, or a context by any other name. Human Development, 21, 108-125.

Brown, A. L., \& Campione, J. C. (1994). Guided discovery in a community of learners. In K. McGilley (Ed.), Classroom lessons : Integrating cognitive theory and classroom practice (pp. 229-270). Cambridge, MA : MIT Press.

Brown, A. L., \& Campione, J. C. (1996). Psychological theory and the design of innovative learning environments : On procedures, principles, and systems. In L. Schauble \& R. Glaser (Eds.), Innovations in learning : New environments for education (pp. 289-325). Mahwah, NJ : Lawrence Erlbaum Associates.

Paavola, S., Lipponen, L., \& Hakkarainen, K. (2004). Models of innovative knowledge communities and three metaphors of learning. Review of Educational Research, 74, 557-576.

Scardamalia, M. (2002). Collective cognitive responsibility for the advancement of knowledge. In B. Smith (Ed.), Liberal education in a knowledge society (pp. 67-98). Chicago, IL : Open Court.

Scardamalia, M., \& Bereiter, C. (2003). Knowledge building. In J. W. Guthrie (Ed.), Encyclopedia of education. Vol. 4 (2 $2^{\text {nd }}$ ed.) (pp. 1370-1373). New York : Macmillan Reference.

Vygotsky, L. S. (1978). Mind in society: The development of higher psychological processes. Cambridge, MA : Harvard University Press.

Zhang, J., Scardamalia, M., Reeve, R., \& Messina, R. (2009). Designs for collective cognitive responsibility in knowledge-building communities. Journal of the Learning Sciences, 18, 7-44. 